\title{
1. Mapping methods in careers research: a review and future research agenda
}

\author{
Jos Akkermans, Colin I.S.G. Lee, Sanne Nijs, Aimilia \\ Mylona, and Janneke K. Oostrom
}

In their 2007 Handbook of Career Studies, Gunz and Peiperl described the careers literature as a Rorschach's test. Indeed, as research on careers is conducted by numerous scholars in a wide variety of disciplines (see Arthur, Hall, \& Lawrence, 1989, pp. 9-10; Gunz \& Peiperl, 2007, p. 3), including psychology, management, and sociology, people's perspectives of the field have long been dependent upon their discipline and niche, as well as their mindset and preconceptions. Following the Academy of Management Careers Division domain statement, ${ }^{1}$ the field of careers research could be characterized as: "people's lifelong succession of work experiences, the structure of opportunity to work, and the relationship between careers and other aspects of life." Major topics in the field range from individual career behaviors to organizational career management, and from labor force diversity to cross-cultural careers, with a career typically being defined as "the unfolding sequence of a person's work experiences over time” (Arthur et al., 1989, p. 8).

Arguably, however, we have come a long way since Gunz and Peiperl's critique. Because of several synthetic reviews of the careers literature (e.g., Akkermans \& Kubasch, 2017; Baruch, Szücs, \& Gunz, 2015; Byington, Felps, \& Baruch, 2019; Lee, Felps, \& Baruch, 2014; Wang \& Wanberg, 2017), a more consistent image has started to emerge of this diverse topic area and the relationships between its subfields. Lee et al. (2014) mapped the existing management literature on careers and found six core categories: international careers, career choice, career management, career adaptation, career success, and life opportunities. The authors conclude that there is a lack of integration between disciplines, and that, for example, management, psychology, education, and sociology could learn from each other to a much greater degree. Baruch et al. (2015) come to a similar conclusion, noting that the field of careers has focused rather narrowly on the individual career agent, for example by emphasizing topics such as career success and employability. Interestingly, the authors speculate that the dominant focus on agentic factors has been fueled by the relative ease with which these factors can be assessed with quantitative methods, and quantitative studies might be easier to publish in most journals.

In line with the reviews from Lee et al. (2014) and Baruch et al. (2015), Akkermans and Kubasch (2017) in their review of five years of careers studies found that the vast majority of them focused on micro-level concepts, and that topics such as career success, career decisions, and employability were the most frequently researched topics. They share Baruch et al.'s conclusion that quantitative studies seem to 
dominate the field, despite the fact that careers journals have no explicit policy on preferring quantitative over qualitative research. Wang and Wanberg (2017) looked specifically at careers research in the field of applied psychology and found similar topics that have been dominant in the field, such as career choice, career success, and career transitions. The authors also conclude that methodologies in careers research seem to have become more sophisticated since the 2000s. Finally, in a review of 23 years of research in the Journal of Vocational Behavior, Byington et al. (2019) again come to a similar conclusion of micro-level topics dominating the field, finding that especially the topics of career choice and worker well-being were prominent in the discourse. They add that a third, separate, category of studies appeared in their results that focused on scale development and validation.

Thus, overall, it seems that despite the inherent diversity within the field of careers (cf. Lee et al., 2014) there is actually a rather consistent picture emerging from recent review studies in terms of the topics that are at the core of the discourse. Yet, although the development of topics in the field of career studies has become much clearer, the development of methods is much less clear. The abovementioned reviews have drawn some preliminary conclusions, such as a dominant focus on quantitative research (Akkermans \& Kubasch, 2017; Baruch et al., 2015), an increasing popularity of validation studies (Byington et al., 2019), and an overall increasing sophistication of methods (Wang \& Wanberg, 2017). However, these claims are not yet firmly substantiated and, as such, our knowledge of the diversity and sophistication of methods used in career studies is still rather limited. Generating such an overview of methods used in careers research would benefit the development of the field because it allows us to accurately track developments in methodologies, their diversity, and their potentially increased sophistication.

For this purpose, we employ a science mapping technique, that builds on bibliometrics (i.e., the quantitative study of academic literatures) and Natural Language Processing (Zupic \& Čater, 2015), to systematically examine the method sections of all papers published in five core careers journals between 2014 and 2018. Specifically, we use the VOSviewer methodology (Van Eck \& Waltman, 2010, 2014) to map methods in careers research and provide an overview of the dominant categories of research methods. This approach has the advantage that it allows a broad purview of literature, forms an aid in the sensemaking process due to its interactive visualizations, and is tailored specifically to the visualization of academic documents. Unsurprisingly, it has been used in hundreds of studies, both within (e.g., Carpini, Parker, \& Griffin, 2017; Markoulli, Lee, Byington, \& Felps, 2017; Parker, Morgeson, \& Johns, 2017; Zhao \& Li, 2019) and beyond (e.g., Fergnani, 2019; Waaijer, Van Bochove, \& Van Eck, 2010; Yeung, Goto, \& Leung, 2017) the management literature. 


\section{METHOD}

Our visualization of the methods used in careers research, was developed in four consecutive stages. First, we compiled a text corpus using the five principal careers journals in the field of management: Career Development International (CDI), Career Development Quarterly (CDQ), Journal of Career Assessment (JCA), Journal of Career Development (JCD), and the Journal of Vocational Behavior (JVB). From these journals, we selected all articles published between 2014 and 2018 and manually extracted the texts from the methods sections. This provided a corpus of 831 methods sections.

In the second stage, we parsed and refined the key technical terms from the methods sections. For this we used the VOSviewer software (version 1.6.11), which identifies technical terms by using Natural Language Processing, to select nouns and any preceding nouns and adjectives. As shown by Justeson and Katz (1995), this noun phrase selection algorithm is an effective way to identify technical terms in texts, independent of the domain.

The initial term list contained 57,702 terms. This list was then reduced to 2,048 terms, by selecting the terms that occurred in 10 or more different documents. This threshold serves to remove idiosyncratic or misspelt terms (see Van Eck, 2011). The refined term list was then coded using a coding scheme inspired by Markoulli et al. (2017) and adopted for the coding of the extracted methods sections. More specifically, we coded the terms with the following labels: "how" (i.e., data collection, analytic technique), "who" (i.e., individual actor, collective actor), "where" (i.e., location), and "what" (i.e., constructs). Terms that did not fit any of the codes were excluded. The terms that could not be coded were typically generic terms or artifacts of the use of academic article texts (e.g., "approach," "et al," "figure"). Finally, any remaining generic terms were removed using the VOSviewer relevance algorithm (Van Eck \& Waltman, 2011, p. 2). This algorithm determines a term's relevance based on its distribution across the documents, and excludes $40 \%$ of the terms with the most nonspecific (i.e., generic) distribution. This led to our final list of 730 terms.

The third stage entailed the visualization of the terms, based on their relatedness. The VOSviewer determines the relatedness of terms using the association strength measure. For each term pair, the association strength is the ratio of co-occurrence between the two terms, over the product of the occurrence counts of the two terms (Rip \& Courtial, 1984; Van Eck \& Waltman, 2010). The VOSviewer then fits the association strengths in a two-dimensional image using the VOS mapping algorithm. This algorithm makes the distances between the terms on the map reflective of their respective association strengths. In other words, it minimizes the difference between the distances and the association strengths (Van Eck, Waltman, Dekker, \& Van den Berg, 2010).

In the fourth and final stage, the subfields were identified using the VOS clustering algorithm (Waltman, Van Eck, \& Noyons, 2010). This algorithm maximizes the sum of the association strengths between terms, while minimizing the size of the clusters, where the ratio is weighted to provide a clustering resolution (i.e., determines the 
size of the clusters). This resolution, like all other settings in the software, was left at its default value, to reduce the risk of imposing our perspective of the field on the visualization. Articles, from the original selection of 831 publications in the core careers journals, were assigned to a cluster when at least $50 \%$ of the terms extracted from its method section were located in the cluster.

\section{FINDINGS}

We found four different clusters based on the method sections of all analyzed papers. Below, we will describe each of the four clusters in detail, after which we will offer some overall observations and conclusions. Figure 1.1 shows a network visualization, where the size of the nodes represent the frequency of occurrence of a term across the 831 method sections and the distance between the terms denotes their relatedness. The full interactive map can be accessed here: http://bit.ly/map pingmethodsincareers. $^{2}$

\section{Green Cluster: Quantitative Methods - Applied Psychology}

The first cluster is the green cluster. This cluster contains 228 terms, which makes it the largest cluster in our overview. We labeled this cluster quantitative methods - applied psychology as the studies within this cluster apply a range of quantitative methods and are mostly situated in the area of applied psychology, often focusing on organizational research related to proactive employee behaviors targeted at one's career or one's job. The most prominent data collection terms within this cluster are Utrecht Work Engagement Scale (UWES), career satisfaction scale, and time lag, and the key data analysis terms are common method variance, best fit, and slope. These terms relate to either the data collection (concurrent vs. longitudinal and single source vs. multiple source), often used scales, or the analysis approach (structural equation modeling and moderation analyses). Key concepts within this cluster are vigor, absorption, and job resource. Of all four clusters, the topics in this cluster occur in the most frequently cited papers. The five most cited articles that we linked to this cluster are those of Zacher (2014a), Tolentino, Garcia, Lu, Restubog, Bordia, and Plewa (2014), Lu, Wang, Lu, Du, and Bakker (2014), Hirschi, Herrmann, and Keller (2015), and Zacher (2014b), with citation rates ranging between 47 and 90. All five articles were published in $J V B$. Looking at the citation numbers per year, the study from Rudolph, Lavigne, and Zacher (2017b), also published in $J V B$, is the one with the highest score of 15.3 times cited per year. This study presents a meta-analysis on the relations between career adaptability and adaptivity, adapting responses, and adaptation results.

The research in this cluster is part of a relatively mature field, relying on quantitative field data in organizations, as indicated by the frequent occurrence of terms such as employee (231 times), response rate (186 times), and company (128 times). The maturity of these topics is also demonstrated by the presence of two meta-analyses 
Mapping methods in careers research 13

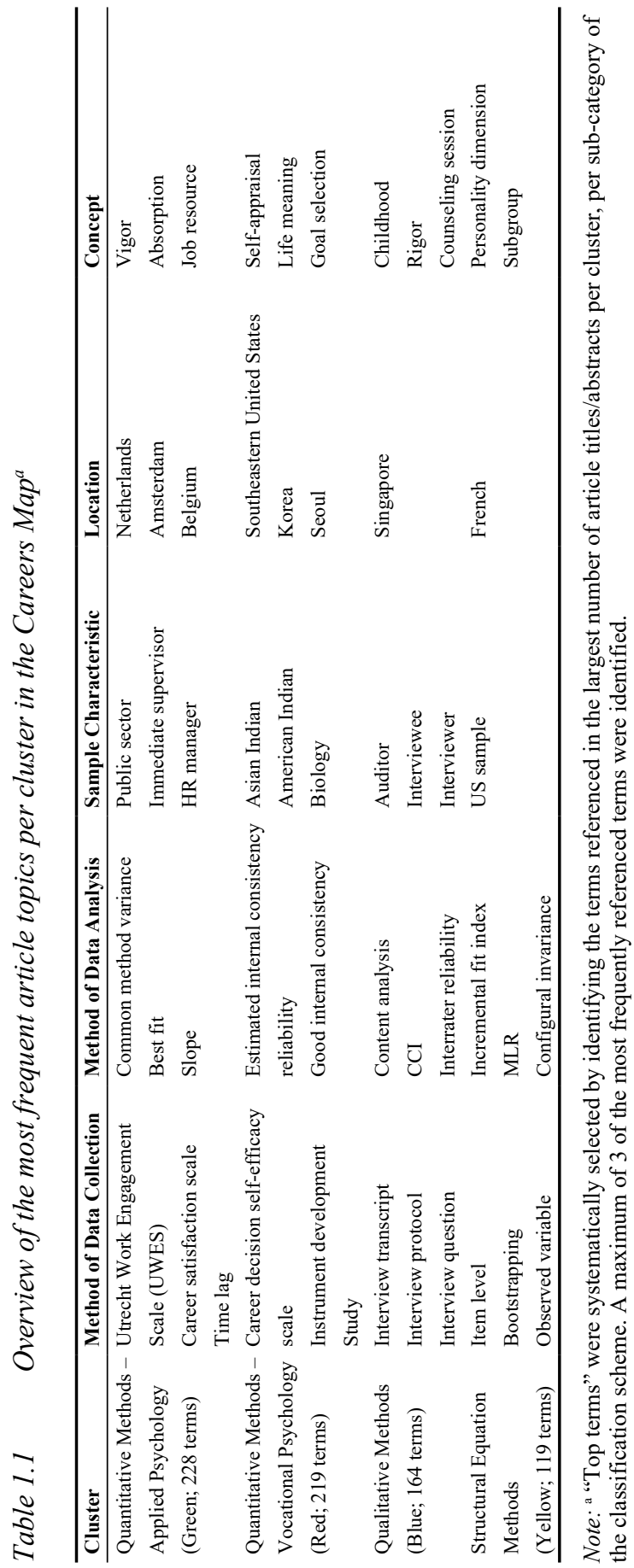




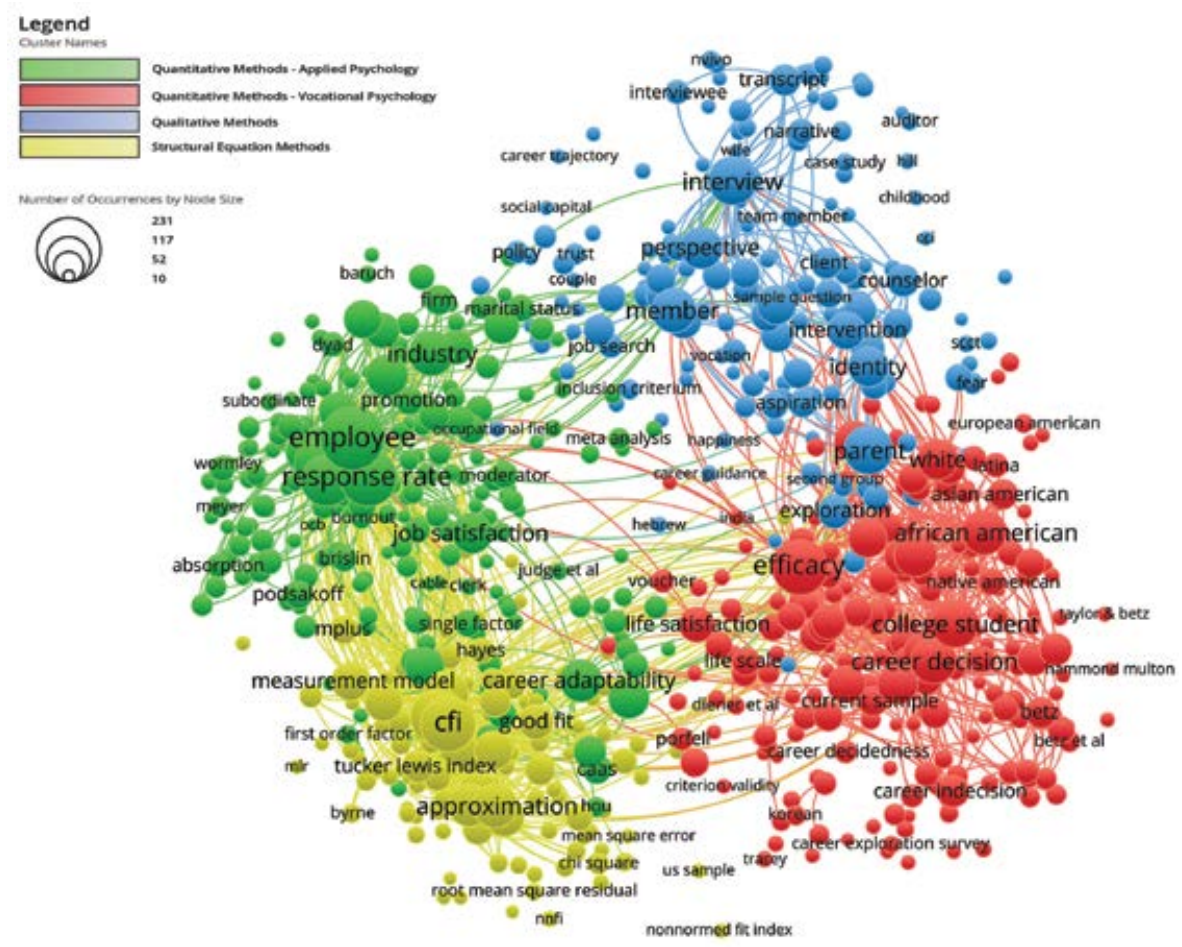

Note: $\quad$ For the interactive map, see: http://bit.ly/mappingmethodsincareers.

Figure 1.1 Science map of career studies methods sections

in this cluster, focusing on the antecedents and outcomes of career adaptability (Rudolph et al., 2017b) and job crafting (Rudolph, Katz, Lavigne, \& Zacher, 2017a). In general, the studies build on validated models and measures, such as the Utrecht Work Engagement Scale (UWES) (Schaufeli, Bakker, \& Salanova, 2006), the Job Crafting Scale (Tims, Bakker, \& Derks, 2012), the Career Satisfaction Scale (Greenhaus, Parasuraman, \& Wormley, 1990), and the Career Adapt-Adaptability Scale (CAAS) (Zacher, 2014a). As the CAAS is a relatively new instrument, the studies within this cluster include several validation studies (e.g., Zacher, 2014a; Öncel, 2014; Tolentino et al., 2014), explaining the frequent occurrences of the terms factor model (90 times) and single factor (43 times). In general, the methodological approaches in this cluster seem to be fairly robust, often involving longitudinal or multiple wave designs (e.g., Harju, Hakanen, \& Schaufeli, 2016; Hirschi et al., 2015; Guan et al., 2014; Lu et al., 2014; Nohe \& Sonntag, 2014), diary studies (e.g., Breevaart, Bakker, \& Demerouti, 2014; Goh, Ilies, \& Wilson, 2015; Zacher, Brailsford, \& Parker, 2014; Zacher, 2015), and employee-supervisor dyads (e.g., 
Demerouti, Bakker, \& Gevers, 2015). It should be noted that the vast majority of the studies with such multiple wave and multi-source designs was published in JVB.

The career crafting studies within the green cluster look at a broad range of predictors and outcomes of career adaptability. The most often studied predictors include personality traits (Zacher, 2014a, Tolentino et al., 2014), self-esteem (Cai et al., 2015), and the outcomes include career satisfaction (Zacher, 2014a) and perceived career growth (Waters, Briscoe, Hall, \& Wang, 2014). The green cluster was also the main cluster for studies on employability (e.g., Forrier, Verbruggen, \& De Cuyper, 2015; Onyishi, Enwereuzor, Ituma, \& Omenma, 2015; Oostrom, Pennings, \& Bal, 2016; Van der Heijden et al., 2018). The job crafting studies mostly build on the job demands-resources (JD-R) model (Bakker \& Demerouti, 2017; Demerouti, Bakker, Nachreiner, \& Schaufeli, 2001). The studies within this cluster concentrate on the outcomes of job crafting, with work engagement being the most often studied outcome (Breevaart et al., 2014; Demerouti et al., 2015; Harju et al., 2016; Lu et al., 2014). There are also studies in this cluster that focus on work-related attitudes, motivation, and well-being, such as Caesens, Stinglhamber, and Luypaert's (2014) study on the impact of work engagement and workaholism on well-being, Akkermans, De Lange, Van Der Heijden, Kooij, Jansen, and Dikkers' (2016) work on age and motivation, and McCallum, Forret, and Wolff's (2014) study on networking behaviors and commitment.

\section{Red Cluster: Quantitative Methods - Vocational Psychology}

The second largest cluster is the red cluster, containing 219 terms. We labeled this cluster quantitative methods - vocational psychology as the studies apply a range of quantitative methods and are mostly situated in the area of vocational psychology and counseling. Prominent data collection terms in this cluster were career decision self-efficacy scale, instrument development, and study, and the key data analysis terms were estimated internal consistency, reliability, and good internal consistency. The prominent concepts were self-appraisal, life meaning, and goal selection. The five most cited papers that were linked to the cluster are Di Fabio and Kenny (2015), Praskova, Hood, and Creed (2014), Moakler and Kim (2014), Allan, Autin, and Duffy (2014), and Navarro, Flores, Lee, and Gonzalez (2014), with citation numbers ranging between 25 and 47 . Two additional articles show up when looking at the number of citations per year. Besides the article of Di Fabio and Kenny (9.4 times per year), which also has the highest number of citations per year, the studies from Fouad, Singh, Cappaert, Chang, and Wan (2016) and Lent, Ireland, Penn, Morris, and Sappington (2017) are a shared runner up with six citations per year. The top-cited papers in this cluster were published showing a larger diversity of journals compared to the green cluster, with $C D Q, J C A, J C D$, and $J V B$ all being represented.

Although all studies in the red cluster use quantitative methods, there is no clear pattern or specific approach that is most dominant. The majority of studies have used correlational and regression analyses, with 20 studies in the top 50 most cited articles testing a mediation model, sometimes in multi-wave studies (e.g., Garcia, 
Restubog, Bordia, Bordia, \& Roxas, 2015; Houlfort, Fernet, Vallerand, Laframboise, Guay, \& Koestner, 2015; Praskova et al., 2014) but also using cross-sectional designs (e.g., Allan et al., 2014; Douglass \& Duffy, 2015; Ezeofor \& Lent, 2014; Miller \& Rottinghaus, 2014). The term moderation was also mentioned 14 times, indicating that the majority of these studies tested a mediation and/or moderation model. However, structural equation modeling techniques are rarely applied in this cluster. The emphasis in this cluster lies on reporting psychometric properties of scales (e.g., scale score, internal consistency, short form), which is in line with the counseling literature that often reports on the quality of counseling tools and techniques (cf. Whiston, Li, Goodrich Mitts, \& Wright, 2017).

A detailed inspection of the map shows two distinct patterns of terms: those related to the samples and those related to the topics used in this cluster. In terms of samples, we observe the dominant use of student and young adult samples, as evidenced by terms such as college student (128 times), undergraduate student (95 times), and sophomore (60 times). In fact, 32 out of the 50 most cited papers used students (27 times) or young people (5 times), which coincides with a predominant focus on early career choices and decisions within the discipline of vocational and counseling psychology (cf. Fouad \& Kozlowski, 2019). Another clear pattern in terms of samples is that the red cluster has many rather specific samples, as shown by often occurring terms such as African American (115 times), Asian American (51 times), Native American (41 times), South Korean (29 times), and Latina (32 times). Most of these studies deliberately focused on these target groups in their research, for example Moakler and Kim (2014) examined whether African American and Latina students would choose a STEM career, Sovet and Metz (2014) who compared the role of parenting style in adolescent career decision-making among French and Korean youth, and Douglass, Duffy, and Autin (2015) who compared experiences of calling among US and Indian workers. At the same time, it also points towards a rather large diversity of samples across the world, including Korea (Jung, Park, \& Rie, 2015), Israel and China (Willner, Gati, \& Guan, 2015), Angola and Mozambique (Lent et al., 2014), Italy (Kozan, Di Fabio, Blustein, \& Kenny, 2014), and Malaysia (Lam \& Santos, 2018).

In terms of the topics, the studies predominantly focus on issues related to vocational psychology and counseling, with the most prominent terms being career decision (124 times), career choice (83 times), life satisfaction (73 times), career indecision (61 times), future career (48 times), and calling (36 times). At the core of these topics is the idea of vocational/career choice and career decisions, for example Fouad et al. (2016) studied whether women would pursue and remain in an engineering career, and Willner et al. (2015) studied career decision-making profiles and their implications for career counselors. Also of note is that Career Construction theory - often in the form of career adaptability as a focal construct - and Social Cognitive Career Theory (SCCT) were often used and tested in the red cluster: among the top 50 most cited studies, 7 studies were about career adaptability, and an additional 13 studies mention SCCT. Career adaptability was studied both as an outcome (e.g., of calling (Praskova et al., 2014; Douglass \& Duffy, 2015) and career decision-making 
self-efficacy (Guan, Capezio, Restubog, Read, Lajom, \& Li, 2016)) and an antecedent (e.g., of academic satisfaction (Duffy, Douglass, \& Autin, 2015)) and life satisfaction (Buyukgoze-Kavas, Duffy, \& Douglass, 2015). SCCT's premises were often tested in different target groups, such as white and Latino engineering major students (Lee, Flores, Navarro, \& Kanagui-Muñoz, 2015), African college students (Lent et al., 2014), and South Korean engineering students (Kim \& Seo, 2014).

\section{Blue Cluster: Qualitative Methods}

The third cluster we identified is the blue cluster. This cluster was labeled the qualitative methods cluster because it reflects the variety of methods, approaches, and instruments mostly used in qualitative research on careers. The cluster contains 164 terms. The most prominent data collection terms in the blue cluster are interview transcript, interview protocol and interview question. The term interview was mentioned a total of 135 times and consequently takes up a central position in the map. The most prominent data analysis terms are content analysis, CCI (i.e., Career Construction Interview) and interrater reliability. Key concepts in the blue cluster are childhood, rigor, and counseling session, which may indicate that qualitative research is especially prominent in the stream of research on vocational psychology and counseling, which often use samples of young individuals. This is supported by the map, which shows considerable overlap between the blue and red clusters. The five most cited articles in the blue cluster are the articles of Lengelle, Meijers, Poell, and Post (2014), Cardoso, Silva, Gonçalves, and Duarte (2014), Lewis, Harris, Morrison, and Ho (2015), Ryba, Ronkainen, and Selänne (2015), and Nota, Santilli, and Soresi (2016). In this top five, the number of citations ranged between 14 and 17 , which is still relatively low. When zooming in on the highest number of citations per year, the article from Nota et al. is the top cited paper with 3.5 citations per year, closely followed by the work of Whiston et al. (2017) with 3.3 citations per year. The top five cited studies in the blue cluster were a mix of articles published in $C D I$, $C D Q$, and $J V B$.

A visual inspection of the map shows that, next to the prominent terms mentioned in Table 1.1, the following terms take up a central position in the blue cluster: parent (139 times), member (117 times), and perspective (103 times). Since these terms give only limited insight into actual methods for data collection and data analysis, we scanned the map for additional terms that help us come to a clearer understanding of the methods used in this cluster. In terms of qualitative methods for collecting and analyzing data, narrative analysis (38 times), case studies (20 times), focus groups (17 times), and content analysis (17 times) were recurring terms. Assessing the interrater reliability seems to be a quality criterion that multiple authors (e.g., Shoffner, Newsome, Minton, \& Morris, 2015; McWhirter, Luginbuhl, \& Brown, 2014) adopt in order to ensure the rigor of their qualitative studies. It is interesting to note that although content analysis and narrative analysis were mentioned rather frequently in this cluster, the term discourse analysis was largely absent in the analyzed articles. Of the 50 most cited articles of this cluster only the article of Simosi, Rousseau, 
and Daskalaki (2015) adopted a grounded theory methodology to study how young professionals describe their career paths in the aftermath of the 2008 Financial Crisis. The Gioia methodology (Gioia, Corley, \& Hamilton, 2013) and Charmaz's approach to Grounded Theory research (Charmaz, 2006) - established approaches for conducting inductive qualitative research - were not explicitly referenced frequently enough to appear on the map.

A closer analysis of the 50 most cited articles in the blue cluster shows that most interview studies (e.g., case studies, focus groups) aim to come to a deeper understanding of changes in vocational identity and/or career outcomes (e.g., Di Fabio, 2016). Accordingly, identity takes up a central position in the map. Multiple articles analyze these topics from a Career Construction perspective. Maree (2016), for example, applied the Career Construction Interview (i.e., CCI) to gain insights into the career-life related challenges black employees experience. Although the majority of these studies was interested in life stories, career transitions, and career changes, only a few authors employed a longitudinal approach, an exception being Lewis et al. (2015), who adopted a qualitative longitudinal research design to study the interplay between life-stages and career transitions for women over a four-year period. Other qualitative studies in this cluster focused on exploring career boundaries and boundarylessness (e.g., Afiouni, 2014; Okay-Somerville \& Scholarios, 2014) as well as international careers and expatriation (e.g., Baruch \& Forstenlechner, 2017; Shortland, 2014).

While most articles included in the blue cluster adopt a qualitative design - hence the label of the cluster - some quantitative studies (e.g., Gross-Spector \& Cinamon, 2018), a meta-analysis (Whiston et al., 2017) and conceptual/review papers (e.g., Akkermans \& Kubasch, 2017; Dispenza, Brown, \& Chastain, 2016) were represented in the cluster. The most impactful non-qualitative studies - in terms of yearly citations - (meta-) analyzed the effectiveness of career interventions on outcomes, such as career adaptability and life satisfaction (Nota et al., 2016), and vocational identity (Whiston et al., 2017). Out of the 50 most cited articles, two articles adopted a mixed method approach: Shortland (2014) combined surveys and semi-structured interviews to investigate how female role models support women to take up expatriate assignments in a male-dominated industry, and Cinamon and Rich (2014) used mixed methods to investigate future work and family roles among at-risk Israeli adolescents.

\section{Yellow Cluster: Structural Equation Methods}

The fourth cluster we identified is the yellow cluster, which consists of 119 terms, considerably less than the 162 to 228 terms in the other clusters. We labeled this cluster structural equation methods, because it contains a relatively large number of articles in which (1) (confirmatory) factor analyses related to the psychometric properties of (new) measures are examined, or (2) structural relations between antecedents and outcomes of career-related variables are examined. The three most prominent data collection terms are item level, bootstrapping, and observed variable, 
and the three most prominent data analysis terms are incremental fit index, MLR (i.e., Multiple Linear Regression), and configural invariance. Key concepts are personality, dimension, and subgroup. The five most cited articles linked to this cluster are, in order of the number of citations, Santilli, Nota, Ginevra, and Soresi (2014), Wilkins, Santilli, Ferrari, Nota, Tracey, and Soresi (2014), Van den Broeck, Sulea, Vander Elst, Fischmann, Iliescu, and De Witte (2014), Fiori, Bollmann, and Rossier (2015), and Sortheix, Chow, and Salmela-Aro (2015). The study of Maggiori, Rossier, and Savickas (2017) had the highest number of citations per year, with 4.7 citations. The top five cited articles in the yellow cluster were all published in $J V B$, with the exception of one article that was published in $C D I$.

A visual inspection of the yellow cluster in the map shows that, next to the prominent terms in the table, the following terms take up a central position based on their number of occurrences: CFI (i.e., comparative fit index; 180 times), approximation (117 times), TLI (i.e., Tucker Lewis index; 79 times), and good fit (70 times). Although structural equation modeling (SEM) as a term does not take up a central place in the map, a closer inspection of the articles and terms shows that articles adopting SEM do not always use the exact same terms when describing their methods (e.g., structural equation, structural equation model, structural equation modeling and structural model). Consequently, the term SEM is underrepresented in the map. However, the frequently occurring words presented above closely relate to this particular approach.

The yellow cluster contains terms from 13 different articles in which new or adapted measures are introduced and their psychometric properties (e.g., underlying factor structures) are tested through SEM analyses. For example, Malo, Tremblay, and Brunet (2016) developed a measurement of Cognitive Adjustment at Work (CAW), Etzel and Nagy (2015) introduced and validated a three-factor model of person-environment fit, Perreira, Morin, Hebert, Gillet, Houle, and Berta (2018) developed a short version of the Workplace Affective Commitment Multidimensional Questionnaire (WACMQ-S), Morgan, de Bruin, and de Bruin (2015) developed the South-African Career Interest Inventory, and Maggiori, Nihil, Froidevaux, and Rossier (2014) introduced a new tool for people preparing for retirement, the Transition to Retirement Questionnaire (TRQ). These validation studies were mostly published in $J C A$ and $J V B$.

The cluster also contains four studies in which SEM is used to test the measurement equivalence of existing measures. Carr and colleagues (Abrams, Lee, Brown, \& Carr, 2015; Carr et al., 2014; Roche, Carr, Lee, Wen, \& Brown, 2017) tested the measurement equivalence of the Career Indecision Profile-65 (CIP-65) between US samples, European samples, and Asian samples. Furthermore, Spurk, Abele, and Volmer (2015) examined the measurement invariance of the Career Satisfaction Scale (CSC) across different occupational groups (e.g., physicians, economists, engineers, and teachers). The remaining articles adopt SEM in both cross sectional studies (e.g., Lichtenthaler \& Fischbach, 2016) and longitudinal studies (e.g., Perera \& Mcllveen, 2014), to test structural relations (i.e., path models) between the antecedents and outcomes of various career-related variables. For example, Santilli et 
al. (2014) examined a partial mediation model between career adaptability and life satisfaction through agency and hope, and Van den Broeck et al. (2014) examined whether qualitative job insecurity is related to counterproductive work behavior via autonomy, belongingness, and competence. Furthermore, Froehlich, Beausaert, Segers, and Gerken (2014) used SEM to study the effect of chronical age and informal and formal learning activities on employability, Preenen, Verbiest, Van Vianen, and Van Wijk (2015) studied the relationship between career competencies and learning, and De Vos, Forrier, Van der Heijden, and De Cuyper (2017) examined the role of occupational expertise in job search intensity.

\section{Overall Observations and Conclusions}

A number of conclusions can be drawn from the analysis of the four clusters that we found when analyzing all published papers in $J V B, C D I, C D Q, J C A$, and $J C D$.

\section{Quantitative research dominates the careers field}

Prior overview studies had already noted that the field of careers research is dominated by quantitative studies (e.g., Akkermans \& Kubasch, 2017; Baruch et al., 2015). Our analysis of the methods used in these studies shows a similar picture as quantitative studies were clearly the most often used, being a prominent part of the green, red, and yellow clusters. However, it should be noted that there was a large diversity of quantitative approaches in these clusters, ranging from scale development, to structural equation modeling, to regression, to group comparisons. These findings shows that the methods in the field are just as diverse as the field is in terms of topics and perspectives (cf. Lee et al., 2014; Gunz \& Peiperl, 2007).

Although quantitative research was clearly dominant, we did find a cluster linked to qualitative research as well. Thus, despite previous observations that qualitative research is not published very often in the field of careers (cf. Akkermans \& Kubasch, 2017), our analysis shows a more nuanced picture. First, qualitative research seems to be predominantly linked to the vocational psychology and counseling literature, and much less to the applied psychology discipline. The map also shows a stronger connection between the blue and red clusters vs. the blue and green clusters. Second, the qualitative methods cluster was not only the smallest in term count, but was also linked to the articles with the fewest citations. This arguably creates a reinforcing pattern, in which there is less qualitative research in the field of career studies, and these studies also get cited less often. If we would speculate further, these findings also seem to show that quantitative and qualitative research communities are rather disconnected, even though the topics they study are often highly similar.

\section{Methods seem to be linked to disciplines and journals}

After analyzing the clusters, we found that the green and red clusters represent two distinct disciplines: although both clusters primarily used quantitative designs, the former was grounded in applied psychology whereas the latter was grounded in vocational psychology and counseling. Some of the key differences between these 
clusters - which fit with existing norms in the respective disciplines - were: (1) the samples (field studies and general worker samples in green vs. student, young adult, and specific target group samples in red), (2) the analysis techniques (SEM in green vs. regression in red), and (3) the most popular topics (proactive work and career behaviors in green vs. career decisions and choices in red). The separation between these two disciplines also becomes clear when looking at the map as the green and red clusters have only very few connecting terms, whereas they are both quite intimately linked to the blue and yellow clusters, with green most strongly to yellow, and red most strongly to blue. This latter observation indicates that although qualitative research and structural methods are used across disciplines, qualitative methods are more often used in vocational psychology, whereas structural methods are more often used in applied psychology. Thus, these findings imply that there is a rather big separation between the applied psychology and vocational psychology disciplines in how they study careers. Our findings support and expand on the conclusion from Fouad and Kozlowski (2019), who note that the mainstream psychology and vocational psychology fields remain separated from each other, a problem that was raised almost 20 years ago and still persists today. Based on our analysis, we can conclude that this does not only hold in terms of topics but also in terms of the methodological approaches used and even the primary journals published in.

Indeed, there also seems to be a difference between journals in this regard. The applied psychology (green) cluster is most strongly represented in $J V B$ and $C D I$, who together make up 160 out of 207 studies in this cluster. The vocational psychology cluster is mostly represented in $J V B$ and $J C A$, who together have 101 of 159 publications in the cluster (of note, $C D I$ only had 1 article in the red cluster). The blue and yellow clusters have a less clear distinction of journals, which also relates to how strongly connected they are to other clusters in the map. In the qualitative methods cluster, $C D I$ (21 articles), $C D Q$ (22 articles) and $J C D$ (23 articles) are almost identical in numbers of articles, whereas $J C A$ ( 7 articles) did not have many articles. An explanation for the latter is that the journal is primarily aimed at assessment and measurement. Of note, $J V B$ was also relatively poorly represented in the blue cluster with only 30 out of 104 articles (whereas $J V B$ had the most papers in all other clusters), indicating that this journal published relatively few qualitative studies in the last five years. The structural equation methods cluster showed the most similarity with the applied psychology cluster in terms of journal outlets, as $J V B$ (14 of 52 articles) and $C D I$ (12 of 52 articles) together made up over half of the cluster. Interestingly, though, $J C A$ was most prominent in the yellow structural equation methods cluster with 20 articles, which would fit with the journal's focus on instrument validation, where structural techniques such as confirmatory factor analyses are commonly applied. $J C D$ (5 articles) and especially $C D Q(1$ article $)$ were poorly represented in the yellow cluster, indicating that these two journals do not publish many studies that apply structural equation methods. 


\section{Methods in careers research are solid yet not always innovative}

Overall, our analysis supports Wang and Wanberg's (2017) conclusion about the increased sophistication of methods in careers research, at least during the past five years. Looking at the entire spectrum of methods and techniques that were used in the studies between 2014 and 2018, we can see that studies have started to incorporate robust designs and analyses. For example, the yellow cluster represents structural methods and validation studies, and the green cluster featured a lot of studies that used SEM techniques. Furthermore, there were quite a lot of studies that used multi-wave designs, both short-term and long-term, and also multiple studies in one paper to cross-validate findings. In all, this means that the field of career studies has not only shed its reputation as a Rorschach's test in terms of topics, but also in terms of methodologies, as they have become increasingly robust in recent years.

At the same time, the vast majority of the research was still rather traditional in terms of methods and techniques. For example, we found only very few quantitative studies that used dynamic within-person designs - such as latent growth models and functional cluster analyses (Hofmans, Vantilborgh, \& Solinger, 2018) - to study processes and changes over time. This would seem to be an ideal approach when studying careers, which are by definition temporal phenomena. Similarly, qualitative research in the field has mostly been static rather than adopting a dynamic design, and recently developed opportunities for analyzing large qualitative samples, for example through text mining (Kobayashi, Mol, Berkers, Kismihók, \& Den Hartog, 2017), have not been mobilized yet in the field. In all, we would cautiously conclude that the field of careers is certainly making progress in terms of quality of methods, yet seems to be somewhat behind on the latest developments that are applied, for example, in organizational behavior and IO psychology research.

\section{RESEARCH AGENDA}

A career is typically defined as a sequence of a person's work experiences that unfold over time (Arthur et al., 1989). This definition implies that careers are, by definition, a temporal and dynamic phenomenon, in which past, current, and future experiences and expectations interact with each other to form career narratives. Although we can conclude from our analyses that researchers are increasingly adopting multiple wave designs - especially in the applied psychology quantitative cluster - we also noticed that, in general, career studies often use methodologies that imply a relatively static and isolated career. That is: studies often focus on short-term processes and developments, and they rarely take into account past and future events or expectations. Interestingly, some studies seem to theoretically embrace the dynamic nature of the career, but do not always align this with methods capable of grasping this dynamic element. We acknowledge the inherent difficulties of setting up long-term studies that can take into account prior and current work experiences, and future expectations of work experiences. Yet, as a first suggestion and in line with a recent call in career sustainability research (De Vos, Van der Heijden, \& Akkermans, 2020; Van der 
Heijden et al., 2020), we challenge scholars - quantitative and qualitative alike - to examine such processes in more detail. For example, a recent qualitative study by Richardson and McKenna (2020) posited that professional sports players in highly physically demanding sports (e.g., rugby, hockey) would have an inherently unsustainable career, yet found that in the long-term their status as a well-known expert often resulted in many opportunities as analysts or for public campaigns. Similarly, while some people engage in career transitions because they want to experience a change, others may be pushed into such changes unexpectedly after experiencing a career shock (e.g., getting a sudden promotion as a positive shock, or being laid off as a negative shock; cf. Akkermans, Seibert, \& Mol, 2018 for a conceptualization and review).

In order to move the field forward, career scholars could focus on sequences of career experiences in their research. Different methods - depending on the specific research question - could be valuable to generate more knowledge on these sequences and transitions. For this purpose scholars could, for example, use narrative analyses in qualitative research (see Chapter 13 by Ferraro), mixed methods studies (see Chapter 15 by Zikic and Voloshyna), and long-term longitudinal data (see Chapter 8 by Dobrow and Weisman). The field of career studies could also benefit from designs used in sociology studies, as these often use longer-term panel studies, such as longitudinal data applied across different countries (e.g., Abendroth, Huffman, \& Treas, 2014) using objective firm data (e.g., Briscoe \& Kellogg, 2011), and examining group-based developmental trajectories (e.g., Frech \& Damaske, 2019). Please note that we are not stating that all research should be temporal, as cross-sectional "snapshots" can be valuable if they fit a particular research question, such as comparing different groups or when studying highly stable predictors of career outcomes (e.g., personality).

A second suggestion for future research in the field of careers is that we would advocate for a stronger cross-over of knowledge and methods between disciplines. In line with previous reviews (e.g., Fouad \& Kozlowski, 2019), we found a rather strict distinction between the disciplines of applied psychology and vocational psychology, as evidenced by their almost complete separation in the map. Although the research questions and topics are generally highly similar - for example studying career success, career decision-making, and career transitions - the approach to studying these research questions differs considerably. Perhaps the best example is the topic of career adaptability, which was prominent in both the applied psychology (e.g., Waters et al., 2014; Zacher, 2014a) and vocational psychology (e.g., Duffy et al., 2015; Praskova et al., 2014) cluster. However, the two disciplines tend to use different methods (e.g., SEM vs. regression), with different samples (e.g., organizational vs. student samples) and focus on different topics (e.g., personality and career success vs. calling and academic satisfaction). More cross-over between disciplines would benefit the field of careers both in terms of consolidating our knowledge of topics as well as methodological approaches. In terms of the latter, when testing mediation and moderation models, studies in vocational psychology can borrow insights from applied psychology in terms of structural equation methods. Conversely, applied psy- 
chology scholars could learn from vocational psychologists in terms of using specific samples and contexts in their research.

In our conclusions and future research suggestions, we have offered various suggestions for mobilizing particular research methods in the field of career studies. However, we want to emphasize that this should not be a goal in itself. Rather, the research question is always leading in the choice of methods. An interesting observation in our results, though, is that certain methodologies seem to be more common in certain disciplines and journals. While this could of course be related to the types of research questions asked, we would speculate that an important reason for this is also the norms and "culture" in a particular discipline, and the policies of the journals that publish the articles. In the field of careers, for example, there seems to be a trend of journals from applied psychology to consider studies with cross-sectional self-report data only in exceptional circumstances, ${ }^{3}$ likely being a key driver of the increase in multiple wave studies in the green cluster. As a final call for future research, we would urge both the people executing the research and those publishing the research that they are aware of such norms and cultures, and assess whether the chosen methods are the most appropriate ones for answering a particular research question. This could open up opportunities for more interdisciplinary research on careers.

\section{NOTES}

1. https://car.aom.org/about-us/new-item2.

2. The map can be viewed on any computer that has the free Java software installed (presently requires version 8 or higher). Once opened, the map file automatically connects to the map data over the user's Internet connection and displays the interactive map. For more information, please see the VOSviewer manual: http://www.vosviewer.com/ download/f-x2y2.pdf.

3. See e.g., https://onlinelibrary.wiley.com/page/journal/20448325/homepage/forauthors .html for a description of the Journal of Occupational and Organizational Psychology deals with cross-sectional self-report data.

\section{REFERENCES}

Abendroth, A.-K., Huffman, M. L., \& Treas, J. (2014). The parity penalty in life course perspective: Motherhood and occupational status in 13 European countries. American Sociological Review, 79(5), 993-1014. doi:10.1177/0003122414545986

Abrams, M. D., Lee, I. H., Brown, S. D., \& Carr, A. (2015). The career indecision profile: Measurement equivalence in the United States and South Korea. Journal of Career Assessment, 23(2), 225-235. doi:10.1177/1069072714535028

Afiouni, F. (2014). Women's careers in the Arab Middle East: Understanding institutional constraints to the boundaryless career view. Career Development International, 19(3), 314-336. doi:10.1108/CDI-05-2013-0061

Akkermans, J., De Lange, A. H., Van Der Heijden, B. I. J. M., Kooij, D. T. A. M., Jansen, P. G. W., \& Dikkers, J. S. E. (2016). What about time? Examining chronological and subjec- 
tive age and their relation to work motivation. Career Development International, 21(4), 419-439. doi:10.1108/CDI-04-2016-0063

Akkermans, J., \& Kubasch, S. (2017). \#Trending topics in careers: A review and future research agenda. Career Development International, 22(6), 586-627. doi:10.1108/CDI-08 $-2017-0143$

Akkermans, J., Seibert, S. E., \& Mol, S. T. (2018). Tales of the unexpected: Integrating career shocks in the contemporary careers literature. SA Journal of Industrial Psychology, 44, e1503. doi:10.4102/sajip.v44i0.1503

Allan, B. A., Autin, K. L., \& Duffy, R. D. (2014). Examining social class and work meaning within the psychology of working framework. Journal of Career Assessment, 22(4), 543-561. doi:10.1177/1069072713514811

Arthur, M. B., Hall, D. T., \& Lawrence, B. S. (1989). Handbook of career theory. New York: Cambridge University Press.

Bakker, A. B., \& Demerouti, E. (2017). Job demands-resources theory: Taking stock and looking forward. Journal of Occupational Health Psychology, 22(3), 273-285. doi:10 .1037/ocp0000056

Baruch, Y., \& Forstenlechner, I. (2017). Global careers in the Arabian Gulf: Understanding motives for self-initiated expatriation of the highly skilled, globally mobile professionals. Career Development International, 22(1), 3-22. doi:10.1108/CDI-12-2015-0164

Baruch, Y., Szücs, N., \& Gunz, H. (2015). Career studies in search of theory: The rise and rise of concepts. Career Development International, 20(1), 3-20. doi:10.1108/CDI-11-2013-0137

Breevaart, K., Bakker, A. B., \& Demerouti, E. (2014). Daily self-management and employee work engagement. Journal of Vocational Behavior, 84(1), 31-38. doi:10.1016/j.jvb.2013 .11 .002

Briscoe, F., \& Kellogg, K. C. (2011). The initial assignment effect: Local employer practices and positive career outcomes for work-family program users. American Sociological Review, 76(2), 291-319. doi:10.1177/0003122411401250

Buyukgoze-Kavas, A., Duffy, R. D., \& Douglass, R. P. (2015). Exploring links between career adaptability, work volition, and well-being among Turkish students. Journal of Vocational Behavior, 90, 122-131. doi:10.1016/j.jvb.2015.08.006

Byington, E. K., Felps, W., \& Baruch, Y. (2019). Mapping the Journal of Vocational Behavior: A 23-year review. Journal of Vocational Behavior, 110, 229-244. doi:10.1016/ j.jvb.2018.07.007

Caesens, G., Stinglhamber, F., \& Luypaert, G. (2014). The impact of work engagement and workaholism on well-being: The role of work-related social support. Career Development International, 19(7), 813-835. doi:10.1108/CDI-09-2013-0114

Cai, Z., Guan, Y., Li, H., Shi, W., Guo, K., Liu, Y., ... Hua, H. (2015). Self-esteem and proactive personality as predictors of future work self and career adaptability: An examination of mediating and moderating processes. Journal of Vocational Behavior, 86, 86-94. doi:10 $.1016 /$ j.jvb.2014.10.004

Cardoso, P., Silva, J. R., Gonçalves, M. M., \& Duarte, M. E. (2014). Narrative innovation in life design counseling: The case of Ryan. Journal of Vocational Behavior, 85(3), 276-286. doi:10.1016/j.jvb.2014.08.001

Carpini, J. A., Parker, S. K., \& Griffin, M. A. (2017). A look back and a leap forward: A review and synthesis of the individual work performance literature. Academy of Management Annals, 11(2), 825-885. doi:10.5465/annals.2015.0151

Carr, A., Rossier, J., Rosselet, J. G., Massoudi, K., Bernaud, J.-L., Ferrari, L., ... Roche, M. (2014). The career indecision profile: Measurement equivalence in two international samples. Journal of Career Assessment, 22(1), 123-137. doi:10.1177/1069072713492930

Charmaz, K. (2006). Constructing grounded theory. A practical guide through qualitative analysis. Thousand Oaks, CA: Sage Publications. 
Cinamon, R. G., \& Rich, Y. (2014). Work and family plans among at-risk Israeli adolescents: A mixed-methods study. Journal of Career Development, 41(3), 163-184. doi:10.1177/ 0894845313507748

De Vos, A., Forrier, A., Van der Heijden, B., \& De Cuyper, N. (2017). Keep the expert! Occupational expertise, perceived employability and job search: A study across age groups. Career Development International, 22(3), 318-332. doi:10.1108/CDI-12-2016-0229

De Vos, A., Van der Heijden, B. I. J. M., \& Akkermans, J. (2020). Sustainable careers: Towards a conceptual model. Journal of Vocational Behavior, 117, 103196. doi:10.1016/j .jvb.2018.06.011

Demerouti, E., Bakker, A. B., \& Gevers, J. M. P. (2015). Job crafting and extra-role behavior: The role of work engagement and flourishing. Journal of Vocational Behavior, 91, 87-96. doi:10.1016/j.jvb.2015.09.001

Demerouti, E., Bakker, A. B., Nachreiner, F., \& Schaufeli, W. B. (2001). The job demandsresources model of burnout. Journal of Applied Psychology, 86(3), 499-512. doi:10.1037/ 0021-9010.86.3.499

Di Fabio, A. (2016). Life design and career counseling innovative outcomes. Career Development Quarterly, 64(1), 35-48. doi:10.1002/cdq.12039

Di Fabio, A., \& Kenny, M. E. (2015). The contributions of emotional intelligence and social support for adaptive career progress among Italian youth. Journal of Career Development, 42(1), 48-59. doi:10.1177/0894845314533420

Dispenza, F., Brown, C., \& Chastain, T. E. (2016). Minority stress across the career-lifespan trajectory. Journal of Career Development, 43(2), 103-115. doi:10.1177/0894845315580643

Douglass, R. P., \& Duffy, R. D. (2015). Calling and career adaptability among undergraduate students. Journal of Vocational Behavior, 86, 58-65. doi:10.1016/j.jvb.2014.11.003

Douglass, R. P., Duffy, R. D., \& Autin, K. L. (2015). Living a calling, nationality, and life satisfaction: A moderated, multiple mediator model. Journal of Career Assessment, 24(2), 253-269. doi:10.1177/1069072715580324

Duffy, R. D., Douglass, R. P., \& Autin, K. L. (2015). Career adaptability and academic satisfaction: Examining work volition and self efficacy as mediators. Journal of Vocational Behavior, 90, 46-54. doi:10.1016/j.jvb.2015.07.007

Etzel, J. M., \& Nagy, G. (2015). Students' perceptions of person-environment fit: Do fit perceptions predict academic success beyond personality traits? Journal of Career Assessment, 24(2), 270-288. doi:10.1177/1069072715580325

Ezeofor, I., \& Lent, R. W. (2014). Social cognitive and self-construal predictors of well-being among African college students in the US. Journal of Vocational Behavior, 85(3), 413-421. doi:10.1016/j.jvb.2014.09.003

Fergnani, A. (2019). Mapping futures studies scholarship from 1968 to present: A bibliometric review of thematic clusters, research trends, and research gaps. Futures, 105, 104-123. doi: 10.1016/j.futures.2018.09.007

Fiori, M., Bollmann, G., \& Rossier, J. (2015). Exploring the path through which career adaptability increases job satisfaction and lowers job stress: The role of affect. Journal of Vocational Behavior, 91, 113-121. doi:10.1016/j.jvb.2015.08.010

Forrier, A., Verbruggen, M., \& De Cuyper, N. (2015). Integrating different notions of employability in a dynamic chain: The relationship between job transitions, movement capital and perceived employability. Journal of Vocational Behavior, 89, 56-64. doi:10.1016/j.jvb .2015 .04 .007

Fouad, N. A., \& Kozlowski, M. B. (2019). Turning around to look ahead: Views of vocational psychology in 2001 and 2019. Journal of Career Assessment, 27(3), 375-390. doi:10.1177/ 1069072719841602

Fouad, N. A., Singh, R., Cappaert, K., Chang, W.-H., \& Wan, M. (2016). Comparison of women engineers who persist in or depart from engineering. Journal of Vocational Behavior, 92, 79-93. doi:10.1016/j.jvb.2015.11.002 
Frech, A., \& Damaske, S. (2019). Men's income trajectories and physical and mental health at midlife. American Journal of Sociology, 124(5), 1372-1412. doi:10.1086/702775

Froehlich, D. E., Beausaert, S., Segers, M., \& Gerken, M. (2014). Learning to stay employable. Career Development International, 19(5), 508-525. doi:10.1108/CDI-11-2013-0139

Garcia, P. R. J. M., Restubog, S. L. D., Bordia, P., Bordia, S., \& Roxas, R. E. O. (2015). Career optimism: The roles of contextual support and career decision-making self-efficacy. Journal of Vocational Behavior, 88, 10-18. doi:10.1016/j.jvb.2015.02.004

Gioia, D. A., Corley, K. G., \& Hamilton, A. L. (2013). Seeking qualitative rigor in inductive research: Notes on the Gioia methodology. Organizational Research Methods, 16(1), 15-31. doi:10.1177/1094428112452151

Goh, Z., Ilies, R., \& Wilson, K. S. (2015). Supportive supervisors improve employees' daily lives: The role supervisors play in the impact of daily workload on life satisfaction via work-family conflict. Journal of Vocational Behavior, 89, 65-73. doi:10.1016/j.jvb.2015 .04 .009

Greenhaus, J. H., Parasuraman, S., \& Wormley, W. M. (1990). Effects of race on organizational experiences, job performance evaluations, and career outcomes. Academy of Management Journal, 33(1), 64-86. doi:10.2307/256352

Gross-Spector, M., \& Cinamon, R. G. (2018). Assessing adults' career exploration: Development and validation of the vocational and maternal identity exploration scales. Journal of Career Development, 45(1), 19-33. doi:10.1177/0894845316667846

Guan, M., Capezio, A., Restubog, S. L. D., Read, S., Lajom, J. A. L., \& Li, M. (2016). The role of traditionality in the relationships among parental support, career decision-making self-efficacy and career adaptability. Journal of Vocational Behavior, 94, 114-123. doi:10 $.1016 /$ j.jvb.2016.02.018

Guan, Y., Guo, Y., Bond, M. H., Cai, Z., Zhou, X., Xu, J., ... Ye, L. (2014). New job market entrants' future work self, career adaptability and job search outcomes: Examining mediating and moderating models. Journal of Vocational Behavior, 85(1), 136-145. doi:10.1016/ j.jvb.2014.05.003

Gunz, H., \& Peiperl, M. (2007). Handbook of career studies. Los Angeles, CA: Sage Publications.

Harju, L. K., Hakanen, J. J., \& Schaufeli, W. B. (2016). Can job crafting reduce job boredom and increase work engagement? A three-year cross-lagged panel study. Journal of Vocational Behavior, 95-96, 11-20. doi:10.1016/j.jvb.2016.07.001

Hirschi, A., Herrmann, A., \& Keller, A. C. (2015). Career adaptivity, adaptability, and adapting: A conceptual and empirical investigation. Journal of Vocational Behavior, 87, 1-10. doi:10.1016/j.jvb.2014.11.008

Hofmans, J., Vantilborgh, T., \& Solinger, O. N. (2018). k-Centres functional clustering: A person-centered approach to modeling complex nonlinear growth trajectories. Organizational Research Methods, 21(4), 915-930. doi:10.1177/1094428117725793

Houlfort, N., Fernet, C., Vallerand, R. J., Laframboise, A., Guay, F., \& Koestner, R. (2015). The role of passion for work and need satisfaction in psychological adjustment to retirement. Journal of Vocational Behavior, 88, 84-94. doi:10.1016/j.jvb.2015.02.005

Jung, H., Park, I.-J., \& Rie, J. (2015). Future time perspective and career decisions: The moderating effects of affect spin. Journal of Vocational Behavior, 89, 46-55. doi:10.1016/j.jvb .2015 .04 .010

Justeson, J. S., \& Katz, S. M. (1995). Technical terminology: Some linguistic properties and an algorithm for identification in text. Natural Language Engineering, 1(1), 9-27. doi:10 $.1017 / \mathrm{S} 1351324900000048$

Kim, M. S., \& Seo, Y. S. (2014). Social cognitive predictors of academic interests and goals in South Korean engineering students. Journal of Career Development, 41(6), 526-546. https://doi.org/10.1177/0894845313519703 
Kobayashi, V. B., Mol, S. T., Berkers, H. A., Kismihók, G., \& Den Hartog, D. N. (2017). Text mining in organizational research. Organizational Research Methods, 21(3), 733-765. 1094428117722619. doi:10.1177/1094428117722619

Kozan, S., Di Fabio, A., Blustein, D. L., \& Kenny, M. E. (2014). The role of social support and work-related factors on the school engagement of Italian high school students. Journal of Career Assessment, 22(2), 345-354. doi:10.1177/1069072713493988

Lam, M., \& Santos, A. (2018). The impact of a college career intervention program on career decision self-efficacy, career indecision, and decision-making difficulties. Journal of Career Assessment, 26(3), 425-444. doi:10.1177/1069072717714539

Lee, C. I. S. G., Felps, W., \& Baruch, Y. (2014). Toward a taxonomy of career studies through bibliometric visualization. Journal of Vocational Behavior, 85(3), 339-351. doi:10.1016/j .jvb.2014.08.008

Lee, H.-S., Flores, L. Y., Navarro, R. R., \& Kanagui-Muñoz, M. (2015). A longitudinal test of social cognitive career theory's academic persistence model among Latino/a and white men and women engineering students. Journal of Vocational Behavior, 88, 95-103. doi:10 $.1016 /$ j.jvb.2015.02.003

Lengelle, R., Meijers, F., Poell, R., \& Post, M. (2014). Career writing: Creative, expressive and reflective approaches to narrative identity formation in students in higher education. Journal of Vocational Behavior, 85(1), 75-84. doi:10.1016/j.jvb.2014.05.001

Lent, R. W., Ireland, G. W., Penn, L. T., Morris, T. R., \& Sappington, R. (2017). Sources of self-efficacy and outcome expectations for career exploration and decision-making: A test of the social cognitive model of career self-management. Journal of Vocational Behavior, 99, 107-117. doi:10.1016/j.jvb.2017.01.002

Lent, R. W., Taveira, M. D. C., Pinto, J. C., Silva, A. D., Blanco, T., Faria, S., \& Gonçalves, A. M. (2014). Social cognitive predictors of well-being in African college students. Journal of Vocational Behavior, 84(3), 266-272. doi:10.1016/j.jvb.2014.01.007

Lewis, K. V., Harris, C., Morrison, R., \& Ho, M. (2015). The entrepreneurship-motherhood nexus: A longitudinal investigation from a boundaryless career perspective. Career Development International, 20(1), 21-37. doi:10.1108/CDI-07-2014-0090

Lichtenthaler, P. W., \& Fischbach, A. (2016). Job crafting and motivation to continue working beyond retirement age. Career Development International, 21(5), 477-497. doi:10.1108/ CDI-01-2016-0009

Lu, C.-Q., Wang, H.-J., Lu, J.-J., Du, D.-Y., \& Bakker, A. B. (2014). Does work engagement increase person-job fit? The role of job crafting and job insecurity. Journal of Vocational Behavior, 84(2), 142-152. doi:10.1016/j.jvb.2013.12.004

Maggiori, C., Nihil, R., Froidevaux, A., \& Rossier, J. (2014). Development and validation of the transition to retirement questionnaire. Journal of Career Assessment, 22(3), 505-523. doi:10.1177/1069072713498684

Maggiori, C., Rossier, J., \& Savickas, M. L. (2017). Career adapt-abilities scale - short form (CAAS-SF): Construction and validation. Journal of Career Assessment, 25(2), 312-325. doi: $10.1177 / 1069072714565856$

Malo, M., Tremblay, I., \& Brunet, L. (2016). Cognitive adjustment as an indicator of psychological health at work: Development and validation of a measure. Journal of Vocational Behavior, 92, 33-43. doi:10.1016/j.jvb.2015.11.005

Maree, J. G. (2016). Career construction counseling with a mid-career black man. Career Development Quarterly, 64(1), 20-34. doi:10.1002/cdq.12038

Markoulli, M. P., Lee, C. I. S. G., Byington, E., \& Felps, W. A. (2017). Mapping human resource management: Reviewing the field and charting future directions. Human Resource Management Review, 27(3), 367-396. doi:10.1016/j.hrmr.2016.10.001

McCallum, S. Y., Forret, M. L., \& Wolff, H.-G. (2014). Internal and external networking behavior: An investigation of relationships with affective, continuance, and normative 
commitment. Career Development International, 19(5), 595-614. doi:10.1108/CDI-08 $-2013-0101$

McWhirter, E. H., Luginbuhl, P. J., \& Brown, K. (2014). ¡Apóyenos! Latina/o student recommendations for high school supports. Journal of Career Development, 41(1), 3-23. doi:10 $.1177 / 0894845312470511$

Miller, A. D., \& Rottinghaus, P. J. (2014). Career indecision, meaning in life, and anxiety: An existential framework. Journal of Career Assessment, 22(2), 233-247. doi:10.1177/ 1069072713493763

Moakler, M. W., \& Kim, M. M. (2014). College major choice in STEM: Revisiting confidence and demographic factors. Career Development Quarterly, 62(2), 128-142. doi:10.1002/j .2161-0045.2014.00075.x

Morgan, B., de Bruin, G. P., \& de Bruin, K. (2015). Constructing Holland's hexagon in South Africa: Development and initial validation of the South African career interest inventory. Journal of Career Assessment, 23(3), 493-511. doi:10.1177/1069072714547615

Navarro, R. L., Flores, L. Y., Lee, H.-S., \& Gonzalez, R. (2014). Testing a longitudinal social cognitive model of intended persistence with engineering students across gender and race/ ethnicity. Journal of Vocational Behavior, 85(1), 146-155. doi:10.1016/j.jvb.2014.05.007

Nohe, C., \& Sonntag, K. (2014). Work-family conflict, social support, and turnover intentions: A longitudinal study. Journal of Vocational Behavior, 85(1), 1-12. doi:10.1016/j.jvb .2014 .03 .007

Nota, L., Santilli, S., \& Soresi, S. (2016). A life-design-based online career intervention for early adolescents: Description and initial analysis. Career Development Quarterly, 64(1), 4-19. doi:10.1002/cdq.12037

Okay-Somerville, B., \& Scholarios, D. (2014). Coping with career boundaries and boundary-crossing in the graduate labour market. Career Development International, 19(6), 668-682. doi:10.1108/CDI-12-2013-0144

Öncel, L. (2014). Career adapt-abilities scale: Convergent validity of subscale scores. Journal of Vocational Behavior, 85(1), 13-17. doi:10.1016/j.jvb.2014.03.006

Onyishi, I. E., Enwereuzor, I. K., Ituma, A. N., \& Omenma, J. T. (2015). The mediating role of perceived employability in the relationship between core self-evaluations and job search behaviour. Career Development International, 20(6), 604-626. doi:10.1108/CDI-09-2014-0130

Oostrom, J. K., Pennings, M., \& Bal, P. M. (2016). How do idiosyncratic deals contribute to the employability of older workers? Career Development International, 21(2), 176-192. doi:10.1108/CDI-08-2015-0112

Parker, S. K., Morgeson, F. P., \& Johns, G. (2017). One hundred years of work design research: Looking back and looking forward. Journal of Applied Psychology, 102(3), 403-420. doi:10.1037/ap10000106

Perera, H. N., \& McIlveen, P. (2014). The role of optimism and engagement coping in college adaptation: A career construction model. Journal of Vocational Behavior, 84(3), 395-404. doi:10.1016/j.jvb.2014.03.002

Perreira, T. A., Morin, A. J. S., Hebert, M., Gillet, N., Houle, S. A., \& Berta, W. (2018). The short form of the workplace affective commitment multidimensional questionnaire (WACMQ-S): A bifactor-ESEM approach among healthcare professionals. Journal of Vocational Behavior, 106, 62-83. doi:10.1016/j.jvb.2017.12.004

Praskova, A., Hood, M., \& Creed, P. A. (2014). Testing a calling model of psychological career success in Australian young adults: A longitudinal study. Journal of Vocational Behavior, 85(1), 125-135. doi:10.1016/j.jvb.2014.04.004

Preenen, P., Verbiest, S., Van Vianen, A., \& Van Wijk, E. (2015). Informal learning of temporary agency workers in low-skill jobs: The role of self-profiling, career control, and job challenge. Career Development International, 20(4), 339-362. doi:10.1108/CDI-12-2013-0158 
Richardson, J., \& McKenna, S. (2020). An exploration of career sustainability in and after professional sport. Journal of Vocational Behavior, 117, 103314. doi:10.1016/j.jvb.2019 .06 .002

Rip, A., \& Courtial, J. (1984). Co-word maps of biotechnology: An example of cognitive scientometrics. Scientometrics, 6(6), 381-400. doi:10.1007/bf02025827

Roche, M. K., Carr, A. L., Lee, I. H., Wen, J., \& Brown, S. D. (2017). Career indecision in China: Measurement equivalence with the United States and South Korea. Journal of Career Assessment, 25(3), 526-536. doi:10.1177/1069072716651623

Rudolph, C. W., Katz, I. M., Lavigne, K. N., \& Zacher, H. (2017a). Job crafting: A meta-analysis of relationships with individual differences, job characteristics, and work outcomes. Journal of Vocational Behavior, 102, 112-138. doi:10.1016/j.jvb.2017.05.008

Rudolph, C. W., Lavigne, K. N., \& Zacher, H. (2017b). Career adaptability: A meta-analysis of relationships with measures of adaptivity, adapting responses, and adaptation results. Journal of Vocational Behavior, 98, 17-34. doi:10.1016/j.jvb.2016.09.002

Ryba, T. V., Ronkainen, N. J., \& Selänne, H. (2015). Elite athletic career as a context for life design. Journal of Vocational Behavior, 88, 47-55. doi:10.1016/j.jvb.2015.02.002s

Santilli, S., Nota, L., Ginevra, M. C., \& Soresi, S. (2014). Career adaptability, hope and life satisfaction in workers with intellectual disability. Journal of Vocational Behavior, 85(1), 67-74. doi:10.1016/j.jvb.2014.02.011

Schaufeli, W. B., Bakker, A. B., \& Salanova, M. (2006). The measurement of work engagement with a short questionnaire: A cross-national study. Educational and Psychological Measurement, 66(4), 701-716. doi:10.1177/0013164405282471

Shoffner, M. F., Newsome, D., Minton, C. A. B., \& Morris, C. A. W. (2015). A qualitative exploration of the STEM career-related outcome expectations of young adolescents. Journal of Career Development, 42(2), 102-116. doi:10.1177/0894845314544033

Shortland, S. (2014). Role models: Expatriate gender diversity pipeline or pipe-dream? Career Development International, 19(5), 572-594. doi:10.1108/CDI-10-2013-0123

Simosi, M., Rousseau, D. M., \& Daskalaki, M. (2015). When career paths cease to exist: A qualitative study of career behavior in a crisis economy. Journal of Vocational Behavior, 91, 134-146. doi:10.1016/j.jvb.2015.09.009

Sortheix, F. M., Chow, A., \& Salmela-Aro, K. (2015). Work values and the transition to work life: A longitudinal study. Journal of Vocational Behavior, 89, 162-171. doi:10.1016/j.jvb .2015 .06 .001

Sovet, L., \& Metz, A. J. (2014). Parenting styles and career decision-making among French and Korean adolescents. Journal of Vocational Behavior, 84(3), 345-355. doi:10.1016/j .jvb.2014.02.002

Spurk, D., Abele, A. E., \& Volmer, J. (2015). The career satisfaction scale in context: A test for measurement invariance across four occupational groups. Journal of Career Assessment, 23(2), 191-209. doi:10.1177/1069072714535019

Tims, M., Bakker, A. B., \& Derks, D. (2012). Development and validation of the job crafting scale. Journal of Vocational Behavior, 80(1), 173-186. doi:10.1016/j.jvb.2011.05.009

Tolentino, L. R., Garcia, P. R. J. M., Lu, V. N., Restubog, S. L. D., Bordia, P., \& Plewa, C. (2014). Career adaptation: The relation of adaptability to goal orientation, proactive personality, and career optimism. Journal of Vocational Behavior, 84(1), 39-48. doi:10.1016/ j.jvb.2013.11.004

Van den Broeck, A., Sulea, C., Vander Elst, T., Fischmann, G., Iliescu, D., \& De Witte, H. (2014). The mediating role of psychological needs in the relation between qualitative job insecurity and counterproductive work behavior. Career Development International, 19(5), 526-547. doi:10.1108/CDI-05-2013-0063

Van der Heijden, B., De Vos, A., Akkermans, J., Spurk, D., Semeijn, J., Van der Velde, M., \& Fugate, M. (2020). Sustainable career across the lifespan: Moving the field forward. Journal of Vocational Behavior, 117, 103344. doi:10.1016/j.jvb.2019.103344 
Van der Heijden, B. I. J. M., Notelaers, G., Peters, P., Stoffers, J. M. M., De Lange, A. H., Froehlich, D. E., \& Van der Heijde, C. M. (2018). Development and validation of the short-form employability five-factor instrument. Journal of Vocational Behavior, 106, 236-248. doi:10.1016/j.jvb.2018.02.003

Van Eck, N. J. (2011). Methodological advances in bibliometric mapping of science. Rotterdam, the Netherlands: Erasmus Research Institute of Management.

Van Eck, N. J., \& Waltman, L. (2010). Software survey: VOSviewer, a computer program for bibliometric mapping. Scientometrics, 84(2), 523-538. doi:10.1007/s11192-009-0146-3

Van Eck, N. J., \& Waltman, L. (2011). Text mining and visualization using VOSviewer. Retrieved from http://arxiv.org/abs/1109.2058

Van Eck, N. J., \& Waltman, L. (2014). Visualizing bibliometric networks. In Y. Ding, R. Rousseau, \& D. Wolfram (Eds.), Measuring scholarly impact: Methods and practice (pp. 285-320). Cham: Springer International Publishing.

Van Eck, N. J., Waltman, L., Dekker, R., \& Van den Berg, J. (2010). A comparison of two techniques for bibliometric mapping: Multidimensional scaling and VOS. Journal of the American Society for Information Science and Technology, 61(12), 2405-2416. doi:10 $.1002 /$ asi.21421

Waaijer, C. J. F., Van Bochove, C. A., \& Van Eck, N. J. (2010). Journal editorials give indication of driving science issues. Nature, 463, 157. doi:10.1038/463157a

Waltman, L., Van Eck, N. J., \& Noyons, E. C. M. (2010). A unified approach to mapping and clustering of bibliometric networks. Journal of Infometrics, 4(4), 629-635. doi:10.1016/j .joi.2010.07.002

Wang, M., \& Wanberg, C. R. (2017). 100 years of applied psychology research on individual careers: From career management to retirement. Journal of Applied Psychology, 102(3), 546-563. doi:10.1037/ap10000143

Waters, L., Briscoe, J. P., Hall, D. T., \& Wang, L. (2014). Protean career attitudes during unemployment and reemployment: A longitudinal perspective. Journal of Vocational Behavior, 84(3), 405-419. doi:10.1016/j.jvb.2014.03.003

Whiston, S. C., Li, Y., Goodrich Mitts, N., \& Wright, L. (2017). Effectiveness of career choice interventions: A meta-analytic replication and extension. Journal of Vocational Behavior, 100, 175-184. doi:10.1016/j.jvb.2017.03.010

Wilkins, K. G., Santilli, S., Ferrari, L., Nota, L., Tracey, T. J. G., \& Soresi, S. (2014). The relationship among positive emotional dispositions, career adaptability, and satisfaction in Italian high school students. Journal of Vocational Behavior, 85(3), 329-338. doi:10.1016/ j.jvb.2014.08.004

Willner, T., Gati, I., \& Guan, Y. (2015). Career decision-making profiles and career decision-making difficulties: A cross-cultural comparison among US, Israeli, and Chinese samples. Journal of Vocational Behavior, 88, 143-153. doi:10.1016/j.jvb.2015.03.007

Yeung, A. W. K., Goto, T. K., \& Leung, W. K. (2017). The changing landscape of neuroscience research, 2006-2015: A bibliometric study. Frontiers in Neuroscience, 11, 120. https://doi.org/10.3389/fnins.2017.00120

Zacher, H. (2014a). Career adaptability predicts subjective career success above and beyond personality traits and core self-evaluations. Journal of Vocational Behavior, 84(1), 21-30. doi:10.1016/j.jvb.2013.10.002

Zacher, H. (2014b). Individual difference predictors of change in career adaptability over time. Journal of Vocational Behavior, 84(2), 188-198. doi:10.1016/j.jvb.2014.01.001

Zacher, H. (2015). Daily manifestations of career adaptability: Relationships with job and career outcomes. Journal of Vocational Behavior, 91, 76-86. doi:10.1016/j.jvb.2015.09.003

Zacher, H., Brailsford, H. A., \& Parker, S. L. (2014). Micro-breaks matter: A diary study on the effects of energy management strategies on occupational well-being. Journal of Vocational Behavior, 85(3), 287-297. doi:10.1016/j.jvb.2014.08.005 
Zhao, H., \& Li, C. (2019). A computerized approach to understanding leadership research. The Leadership Quarterly, 30(4), 396-416. https://doi.org/10.1016/j.leaqua.2019.06.001

Zupic, I., \& Cater, T. (2015). Bibliometric methods in management and organization. Organizational Research Methods, 18(3), 429-472. doi:10.1177/1094428114562629 